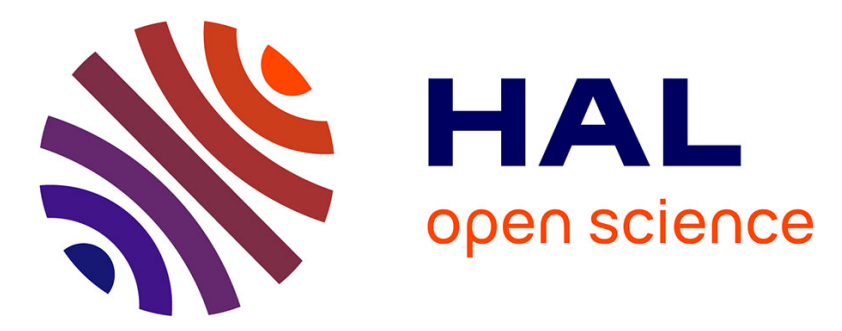

\title{
Role of fluorine in the transfer of Be and the formation of beryl deposits: a thermodynamic model.
}

Claire Ramboz

\section{To cite this version:}

Claire Ramboz. Role of fluorine in the transfer of Be and the formation of beryl deposits: a thermodynamic model.. Comptes Rendus Géoscience, 2005, 337, pp.639-640. 10.1016/j.crte.2005.03.007 . hal-00023371

\section{HAL Id: hal-00023371 \\ https://hal-insu.archives-ouvertes.fr/hal-00023371}

Submitted on 23 May 2006

HAL is a multi-disciplinary open access archive for the deposit and dissemination of scientific research documents, whether they are published or not. The documents may come from teaching and research institutions in France or abroad, or from public or private research centers.
L'archive ouverte pluridisciplinaire HAL, est destinée au dépôt et à la diffusion de documents scientifiques de niveau recherche, publiés ou non, émanant des établissements d'enseignement et de recherche français ou étrangers, des laboratoires publics ou privés. 


\section{Role of fluorine in the transfer of $\mathrm{Be}$ and the formation of beryl deposits: a thermodynamic model}

\section{Claire Ramboz}

Institut des sciences de la Terre d'Orléans (ISTO), CNRS, IA, rue de la Férollerie, 45071 Orléans cedex 2, France

After a thorough study on the tracing of the emerald origin by oxygen data by Zwaan et al. [12], the paper by Moine et al. [4] entitled 'The role of fluorine in the formation of the Mananjary emerald deposits (eastern Madagascar)' demonstrates through a thermodynamic model that the metasomatic transformation of amphibolites into fluorine-enriched phlogopites was the cause for beryl precipitation.

- This paper is important as it shows that fluorine can be a dominant ligand for some metals, like beryllium. As underlined by the authors, the reason for the Be__F affinity in solution is that beryllium, despite the fact it is divalent, still displays a high ionic potential due to its small ionic radius.

- Moine et al. [4] calculate that a fluid equilibrated with F-phlogopite $\left(\underline{X_{F}}=0.7\right)$ at $500^{\circ} \mathrm{C}$ and $2 \mathrm{kbar}$ contains $275 \mathrm{ppm}$ total fluorine, compared to $55 \mathrm{ppm}$ dissolved in fluids buffered by wollastonite-quartz-fluorite (WQF) in the same conditions [11]. This paper therefore contributes to enlighten that fluorine-rich fluids can circulate through rocks in some natural geological settings. More precisely, it shows that rocks dominantly formed of hydrous silicates constitute a remarkable environment where are contradicted previous conclusions in the literature that "fluoride concentrations in natural hydrothermal solutions are restricted by equilibrium constraints involving fluorite, topaz and other fluoride-bearing minerals with low solubilities" (e.g., [2] and references therein).

- The numerous local crystal-chemical factors that control (OH-F) exchanges in hydrous silicates (smectites, micas, amphiboles, tourmalines) are far from being understood and modelled for any given composition. However, this paper is a good illustration of the fact that, at least for a limited number of amphibole and biotite end-members with restricted Fe-free Mg-rich compositions, a thermodynamic database is now available that satisfactorily accounts for fluorination reactions. Numerous systematic structural studies of synthetic end-members have shown that some magnesian minerals like talc, phlogopite or tremolite, host the hydroxyl group in a symmetrical trioctahedral ${ }_{36}\left[\mathrm{Mg}_{3}\right]$ environment. Fluorination of such minerals is easy in all proportions and controlled by simple local crystal-chemical parameters. Firstly, there is no steric limitation to the complete substitution of $\mathrm{OH}^{-}$by $\mathrm{F}^{-}$in these minerals because the ionic radii of these two anions are very similar. Also, the proton 
exchanges one charge with the hydroxyl oxygen and is independent of any lattice atom. Such a hydroxyl group, which behaves as a separate entity, can easily be replaced by fluorine [8].

Robert and co-workers [7] have tentatively suggested that, in micas, those hydroxyls with stretching vibrations showing the highest wavenumbers are more easily replaced by fluorine under hydrothermal conditions. The data collected in table 1 suggest that this inference extends to talc and amphiboles.

\begin{tabular}{|l|l|l|l|l|l|}
\hline & $\begin{array}{l}\text { (OH-F) } \\
\text { musc ovite }\end{array}$ & $\begin{array}{l}\text { (OH-F) } \\
\text { talc }\end{array}$ & $\begin{array}{l}\text { (OH-F) } \\
\text { tremolite }\end{array}$ & $\begin{array}{l}\text { (OH-F) Na- } \\
\text { pargasite }\end{array}$ & $\begin{array}{l}\text { (OH-F) } \\
\text { phlogopite }\end{array}$ \\
\hline$\underline{X_{F}}$ (solid) & 0.01 & $0.12-$ & $0.23-$ & & 0.61 \\
\hline$\underline{\frac{V O H}{\left(\mathrm{Cm}^{-1}\right)}}$ & 3630 & 3677 & 3674 & $3710^{\circ}(3678)$ & 3725 \\
\hline
\end{tabular}

Table 1. : $\underline{X}_{F}$ (solid): Atomic fraction of $F$ in the hydroxyl-site of some hydrous silicates calculated at $500^{\circ} \mathrm{C}$ and $1 \mathrm{kbar}$ in a fluid equilibrated with the WQF buffer (after [11]). $\mathrm{VOH}$ : Main $\mathrm{OH}$-stretching vibration in muscovite [3] and various Mg-hydrous silicates (after [8], [9] and [10])

?On crystallographic bases, $(\mathrm{OH}, \mathrm{F})$ exchanges should be quite similar in talc and tremolite. Probably, the different $\underline{X}_{F}$ values calculated for these two phases reflect inaccurate thermodynamic data for the four (OH, F) end-members (M.-L. Pascal, pers. commun.). ${ }^{\circ}$ In pargasite, only the $\mathrm{OH}$ groups bonded to $\mathrm{Mg}_{3}$, yielding the band at $3710 \mathrm{~cm}^{-1}$, can be quantitatively replaced by fluorine and not the $\mathrm{OH}$ groups bonded to $\mathrm{Mg}_{2} \mathrm{Al}$ [9].

The reason why $\mathrm{OH}$-stretching vibrations are higher in phlogopite than in talc, pargasite or tremolite is the $\mathrm{K}^{+}-\mathrm{H}^{+}$repulsion between the A-cation and the hydroxyl proton [8]. Thus, local crystal-chemical features explain why phlogopite is a larger sink for fluorine than Al-bearing amphiboles. This property in turn explains that the onset of F-enriched biotite formation at the expense of amphibole is coincident with the destabilisation of $\mathrm{Be} \_\mathrm{F}$ complexes in solution, as calculated by Moine et al. [4].

Finally, two conclusions derived by Moine et al. [4] from their model can be extended to most fluorination reactions, on the basis of crystal-chemical data. (i) These reactions will always favour fluid saturation with respect to Al-phases like corundum or beryl, as they quite systematically induce a decrease in the Al-content of the fluorinated silicate ('the Al-avoidance rule' [1], [5] and [6]). (ii) Fluorination of hydrous silicates is favourable to metasomatic exchanges as it generates porosity. Indeed, this process induces a contraction of the amphiboles, at least up to $\underline{X_{F}=0.5}$ (e.g., [8] and [10]). This is all the more so in phlogopite as the $\mathrm{K}^{+}-\mathrm{F}^{-}$attraction further decreases the cell parameters in the whole composition range from phlogopite to F-phlogopite. 


\section{References}

[1] B. Boukili, F. Holtz, J.-M. Bény and J.-L. Robert, Fe__F and Al_F avoidance rule in ferrous-aluminous (OH, F) biotites, Schweiz. Mineral. Petrogr. Mitt. 82 (2002) (3), pp. 549-559.

[2] K.J. Jackson and H.C. Helgeson, Chemical and thermodynamic constraints on the hydrothermal transport and deposition of tin. I. Calculations of the solubility of cassiterite at high pressures and temperatures, Geochim. Cosmochim. Acta 49 (1985), pp. 1-22.

[3] K. Langer, N.D. Chatterjee and K. Abraham, Infrared studies of some synthetic and natural 2Ml dioctahedral micas, N. Jahrb. Mineral. Abh. 142 (1981), pp. 91-110.

[4] B. Moine, C. Chan Peng and A. Mercier, Rôle du fluor dans la formation des gisements d'émeraude de Mananjary (Est de Madagascar), C. R. Geoscience 336 (2004), pp. 513-522.

[5] J.L. Munoz and S.D. Luddington, Fluoride-hydroxyl exchange in biotite, Am. J. Sci. 274 (1974), pp. 396-413.

[6] A. Papin, J. Sergent and J.-L. Robert, Intersite $\mathrm{OH}-\mathrm{F}$ distribution in an Al-rich synthetic phlogopite, Eur. J. Mineral. 9 (1997), pp. 501-508. Abstract-GEOBASE

[7] J.-L. Robert, G. Della Ventura, J.-M. Bény and M. Hardy, Fluorine in micas: crystalchemical controls of the $\mathrm{OH}_{2} \mathrm{~F}$ distribution between trioctahedral and dioctahedral sites, Eur. J. Mineral. 5 (1993), pp. 7-18. Abstract-GEOBASE

[8] J.-L. Robert, G. Della Ventura, M.D. Welch and F.C. Hawthorne, Near-infrared study of short-range disorder of $\mathrm{OH}$ and $\mathrm{F}$ in monoclinic amphiboles, Am. Mineral. 84 (1999), pp. 86-91.

[9] J.-L. Robert, G. Della Ventura, M.D. Welch and F.C. Hawthorne, The OH-F substitution in synthetic pargasite at $1.5 \mathrm{kbar}, 850^{\circ} \mathrm{C}$, Am. Mineral. 85 (2000), pp. $926-$ 931.

[10] R.W.T. Wilkins and J. Ito, Infrared spectra of some synthetic talcs, Am. Mineral. 52 (1967), pp. 1649-1661.

[11] C. Zhu and D.A. Sverjensky, Partitioning of $\mathrm{F}-\mathrm{Cl}-\mathrm{OH}$ between minerals and hydrothermal fluids, Geochim. Cosmochim. Acta 55 (1991), pp. 1837-1858.

[12] J.-C. Zwaan (Hanco), A. Cheilletz and B.E. Taylor, Tracing the emerald origin by oxygen isotope data: the case of Sandawana, Zimbabwe, C. R. Geoscience 336 (2004), pp. 41-48. 